\title{
Effects of gamma irradiation on the alkaloid content in seeds of Datura stramonium and the radiosensitivity of derived seedlings
}

\author{
Nabila Benslimani ${ }^{*}$, Madjda Khelifi-Slaoui ${ }^{2}$, Abdelkader Morsli $^{2}$, Amar Djerrad ${ }^{1}$, Ezz Al-Dein Al- \\ Ramamneh $^{3}$, Abdullah Makhzoum ${ }^{4 *}$ \&akhdar Khelifi ${ }^{2}$
}

${ }^{1}$ Centre de Recherche Nucléaire d’Alger. 02 Bd. Frantz Fanon BP-399 Alger-RP, 16000, Alger, Algérie

${ }^{2}$ LRGB, Ecole Nationale Supérieure Agronomique (ES1603), El Harrach, Algérie

${ }^{3}$ Department of Agricultural Sciences, AL-Shouback University College, Al-Balqa Applied University, AL -Shouback, Maan, Jordan

${ }^{4}$ Department of Biological Sciences \& Biotechnology, Botswana International University of Science and Technology. Botswana

\section{Article history}

Received: 15 September 2019

Accepted: 09 November 2019

Published: 21 December 2019

\section{Publisher}

Horizon e-Publishing Group

\author{
*Correspondence \\ Nabila Benslimani \\ 凶nbenslimani@yahoo.fr \\ Abdullah Makhzoum

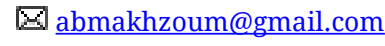

\begin{abstract}
Tropane alkaloids are a group of secondary metabolites occurring naturally in Solanaceae family as Atropa belladona, Datura stramonium, Mandragora officinalis, and Hyoscyamus niger. These molecules have valuable therapeutic applications, for example, atropine and hyoscyamine are utilized as antimuscarinic besides being stomach and intestinal diseases drugs. Plants of the Solanaceae family can provide a natural yet less expensive source of these compounds. Hitherto, in order to emphasize these metabolites biosynthesis, $D$. stramonium seeds were irradiated using a cobalt- 60 source of gamma rays of 5 to 80 Gy and germinated in vitro on MS medium in growth controlled chamber. Mutagenesis of $D$. stramonium seeds was attempted aiming at obtaining plants from in vitro source that are genetically variable for enhancing the biosynthesis of secondary metabolites, namely alkaloids. Results indicated that $D$. stramonium seeds exhibited a good radiosensitivity and the mutagen damage index GR (30-50) for D. stramonium was determined at $80 \mathrm{~Gy}$. The Characterization of alkaloids (Atropine and hyoscyamine) was done by infrared spectroscopy which showed that alkaloids content of the irradiated seeds is altered by irradiation as the reference bands were not found with all doses used. In addition, seedlings grown from irradiated in vitro seeds exhibited remarkable morphological variations that varied based on the employed dose of gamma rays. These findings permitted the selection of the optimal irradiation dose $(80 \mathrm{~Gy})$ to induce mutations that are likely to prompt changes at genetic and metabolic level of the targeted alkaloids.
\end{abstract}

Keywords: Alkaloids; Datura; In vitro culture; Mutation; Radiosensitivity

Citation: Benslimani N, Slaoui M K, Morsli A, Djerrad A, Al-Ramamneh E A, Makhzoum A, Khelifi L. Effects of gamma irradiation on the alkaloid content in seeds of Datura stramonium and the radiosensitivity of derived seedlings. Plant Science Today 2019;6(4):533540. https://doi.org/10.14719/pst.2019.6.4.634

Copyright: (c) Benslimani et. al. (2019). This is an open-access article distributed under the terms of the Creative Commons Attribution License, which permits unrestricted use, distribution, and reproduction in any medium, provided the original author and source are credited (https://creativecommons.org/licenses/by/4.0/).

Indexing: Plant Science Today is covered by Scopus, Web of Science, BIOSIS Previews, ESCI, CAS, AGRIS, UGC-CARE, CABI, Google Scholar, etc. Full list at http://www.plantsciencetoday.online

\section{Introduction}

Datura, a member of the produces various alkaloids
Solanaceae family, such as atropine, scopolamine and hyoscyamine $(1,2)$. These secondary metabolites induce in humans and animals various physiological responses by interfering with the neurotransmitters. In the case 
of atropine for example, muscles activity are regulated by the parasympatic nervous system. This occurs because atropine is a competitive antagonist of the muscarinic acetylcholine receptors. Therefore, it may cause swallowing difficulties, reduced salivation and bronchial excretions $(3,4)$. Most of the alkaloids are toxic in high doses, but have important therapeutic properties in low doses (5). Tropane alkaloids or their derivatives are commonly used as muscle relaxants, analgesics, tranquilizers or even as psychotropic drugs. They also act as antispasmodic, sedative, anticholinergic and mydriatic substances $(6,7)$.

In fact, the chemical synthesis of these alkaloids is more expensive than their extraction from plants. Interestingly, through biotechnological tools, the enhancement of secondary metabolite production from plants in vitro became recently feasible. Indeed, various strategies have been adopted for improving the production of secondary metabolites in plants. More recently, emergence of DNA recombination technology has opened a new avenue for altering gene expression regulations related to biosynthesis of metabolites $(8,9)$. In vitro culture with growth regulators offers a promising alternative in comparison with open field culture or chemical synthesis (10). It was reported higher alkaloid contents in cell suspensions of Datura innoxia Mill. compared to that in whole plants (11).

Importantly, hairy roots have been extensively investigated in many medicinal plant species (12-20) as well as other applications in plant molecular pharming and phytoremediation (14, 21-23). Hairy root culture, in comparison to cell suspension cultures, provide a good source for continuous production of secondary metabolites and is characterized by its genetic stability and ability to produce a variety of chemical compounds (8). These transformed roots represent an interesting system to produce many secondary metabolites as Indole and Tropane Alkaloids (2426).

Additionally, other studies have demonstrated an enhanced production of tropane alkaloids in transgenic hairy root cultures via Agrobacterium rhizogenes $(17,27)$. Factors that can increase alkaloids production by hairy roots involve optimization of culture medium components, elicitor-mediated stimulation of secondary metabolites and the efficient use of competent tissues (28). Induction of mutagenesis could be an alternative strategy to improve alkaloid production. Gamma irradiation causes mutations in plants by changing DNA structure and function and consequently can enhance metabolites biosynthetic pathways (29). According to our best knowledge; mutagenesis has never been investigated in Datura plants for improving tropane alkaloid contents. This work aimed at studying tropane alkaloids profile in irradiated
Datura stramonium using IR spectrometer. Thus, the effects of irradiation doses on in vitro seed germination and the growth of resulting seedlings were assessed. This report provides bases to estimate radiosensitivity of Datura stramonium seeds, and to determine the optimal dose to be applied for optimizing the optimal mutations induction rate and effects on the biosynthesis of molecules of interest.

\section{Materials and Methods}

\section{Plant material}

Seeds of Datura stramonium L were harvested in the locality of El Harrach, Algiers, then scarified and disinfected as described by (30). Seeds were dipped in ethanol at $70^{\circ} \mathrm{C}$ for 30 seconds, followed by passing through sodium hypochlorite at $12^{\circ} \mathrm{C}$ for 10 minutes and then rinsed three times in sterile distilled water. Finally, seeds were dried on sterile blotting paper. Disinfected seeds were planted in test tubes containing $10 \mathrm{ml}$ of MS culture medium (31). The tubes were then placed in a growth chamber at $26 \pm 1^{\circ} \mathrm{C}$ with a photoperiod of 16 hours.

\section{Irradiation of seeds}

The seeds of Datura were divided into homogenous lots of 50 seeds in glass tubes and gamma irradiated at different doses $(0,5,10,20$, 40, 60 and 80 Gy) (32). These doses were determined following the recommendations of (26). The irradiation of Datura stramonium seeds was carried out at the nuclear application division of the Algiers nuclear research center at a rate of $0.623 \mathrm{~Gy} / \mathrm{mn}$. During irradiation, a cobalt-60 gamma radiation source was used. The pilot irradiation of the Algerian Nuclear research center is composed of three cylindrical cobalt-60 sources. They are arranged vertically in a source holder of stainless steel. The dimension of the sources is 384 $\mathrm{mm}$ in height and $26.6 \mathrm{~mm}$ in diameter. They form an active height of $1152 \mathrm{~mm}$.

\section{Hyoscyamine and scopolamine analysis by infrared spectrometry}

The control and irradiated seed samples were finely ground and dried for $24 \mathrm{~h}$ at $45^{\circ} \mathrm{C}$. A quantity of $0.1 \mathrm{~g}$ of $\mathrm{kBr}$ (potassium bromide) was added to each sample of the seed powder followed by drying in an oven at $50^{\circ} \mathrm{C}$. The pellets were subjected to IR spectrometer (Chromatography Nicolet 380 FT-IR) for infrared chromatography detection of the two alkaloids targets (hyoscyamine and scopolamine).

\section{Radiosensitivity study}

Few criteria have been taken into account to study the radiosensitivity (33). These characteristics such as germination percentage, stem and root length, and rate of increase or decrease in the average length of stems and roots of seedlings derived 
from in vitro culture of irradiated (exposed to different irradiation doses) and no-treated seeds were determined 90 days after culture on a synthetic culture medium (31). To determine matugen damage index, Analysis of Variance (ANOVA) was performed for data concerning average stem and root length of seedlings derived from irradiated and non-treated seeds and means were compared at 0.05 and 0.01 significance levels.

\section{Results}

\section{Characterization of irradiated seeds alkaloids by infrared spectrometry}

The spectra for alkaloids as shown in Fig. 1 were obtained by infrared spectrometry from control and irradiated Datura stramonium seeds (at different irradiation doses). Formation of amines was detected in the range of 3300 to 3500 vibrations $\mathrm{cm}^{-1}$. The lack of bands in this region indicated most likely the presence of a tertiary amine. The $\mathrm{OH}$ bond $(\mathrm{O}-\mathrm{H})$ formation is evident by the stretching mode located at $3600 \mathrm{~cm}^{-1}$, whereas the absorption frequency of the $\mathrm{C}-\mathrm{N}$ bond appears at $1300 \mathrm{~cm}^{-1}$.

\section{Scopolamine}

Analysis of the spectra obtained for alkaloids by infrared spectrometry in the control and irradiated seeds of Datura stramonium at different irradiation doses is presented in Table 1. It is shown for scopolamine that the main bands contained in the standard spectrum indicated by (34) are not fully recovered in the spectra from the control and irradiated seeds except for the band $1730 \mathrm{~cm}^{-1}$ which is found at all doses (Table 1a). The standard band $853 \mathrm{~cm}^{-1}$ (C - $\mathrm{H}$, aromatic) is found only in D5. The $1166 \mathrm{~cm}^{-1}$ band (C- N, aliphatic amines) exists at all doses except D2, D4 and D5. The $736 \mathrm{~cm}^{-1}$ band (C- $\mathrm{H}$, aromatic) appears only at D0 and D6. The $705 \mathrm{~cm}^{-1}$ band (C- H, aromatics) existed neither in the D0 nor in the other doses. Finally, the $1047 \mathrm{~cm}^{-1}$ band (C- 0, alcohol, carboxylic acid) was found only in the control (D0) (34) (Table 1a, Fig. 1).

\section{Hyoscyamine}

The $1720 \mathrm{~cm}^{-1}$ band $(\mathrm{C}=0$, saturated aliphatic aldehydes) is found in all doses tested (Table $1 \mathrm{~b}$ ). The bands: $1035 \mathrm{~cm}^{-1}, 1153 \mathrm{~cm}^{-1}$ and $1063 \mathrm{~cm}^{-1}$ (C $\mathrm{N}$, aliphatic amines) were not found in any doses. The doses D2, D4 and D5 did not produce $1163 \mathrm{~cm}^{-1}$ band (C-H, Alide Alkyl). Only dose D3, among the tested doses of gamma irradiation, has exhibited the spectral band at $1204 \mathrm{~cm}^{-1}(\mathrm{C}-\mathrm{N}$, aliphatic amines) (Table 1b, Fig. 1).

This investigation reported the production of the secondary metabolites scopolamine and hyoscyamine in Datura stramonium seeds that were exposed to gamma irradiation at doses ranging from 5 to $80 \mathrm{GY}$. The identification of alkaloids in control and irradiated material following the specification of (35), with regard to wavenumber $\left(\mathrm{cm}^{-1}\right)$ indicated the presence of the functional groups $\left(\mathrm{OH}\right.$ located at $3600 \mathrm{~cm}^{-1}$, C-N located at $1300 \mathrm{~cm}^{-1}$ ) and amines (most likely tertiary amines) at 3300 to $3500 \mathrm{~cm}^{-1}$ (Fig. 1). Furthermore, Comparison with scopolamine and hyoscyamine standard bands indicated the presence of $\mathrm{C}=\mathrm{O}\left(1732 \mathrm{~cm}^{-1}\right), \mathrm{C}-\mathrm{O}\left(1170 \mathrm{~cm}^{-1}\right)$ and CO-C $\left(858 \mathrm{~cm}^{-1}\right)$ functional groups (Table $\left.1 \mathrm{a}, \mathrm{b}\right)(36)$.

\section{Discussion}

Infrared spectroscopy shows that alkaloids contained in seeds are altered by irradiation because reference bands, except $1730 \mathrm{~cm}^{-1}$ band of scopolamine and $1720 \mathrm{~cm}^{-1}$ of hyoscyamine are not found in response to all doses. The absence or presence of infrared bands (Table 1a, b), may be explained by the changes at the molecular level induced by the radiation energy applied to seeds. Plant genes react differently to radiation as certain genes would be more expressive than others. Moreover, genes were shown to be up-regulated and down-regulated by gamma-irradiation as reported in Arabidopsis thaliana (37). This could be due to variations in repair of DNA sequence damage or the presence of redundant genes or changes in gene structure and function features $(38,39)$. Indeed, Gamma rays interact with the atoms and molecules for creating free radicals that alter the major components of plant cells. These radicals affect morphogenesis, plant biochemistry and physiology according to applied doses of gamma (40, 41).

\section{Effects of irradiation on seed radiosensitivity}

Fig. 2 shows that seed germination percentage varied with radiation dose. Germination $\%$ was the highest (96.07) in D2 treated seeds, and the lowest (85.24) with D5. In general, the percentage of seed germination was enhanced by all doses except D5 that exhibited a slight decline in germination capacity.

Variance analysis confirms a highly significant dose effect on average stem and root length. Fig. 3 shows that the highest average stem length is recorded at D2 $(8.42 \mathrm{~cm})$, while the lowest average length is recorded at D6 $(4.93 \mathrm{~cm})$. LSD (Least significant difference) showed four homogeneous groups that were quite often overlapping. The variation coefficient with regard to stem length ranges from 57 to $82 \%$, which indicates the existence of a high variability in the response of treated seeds. Variance analysis for root length also indicated a highly significant effect of radiation dose (Fig. 3). LSD test revealed two groups, group A being represented by D6 and group $B$ by the other doses. The coefficient of variation (about 71.48) indicated the existence of a wide variability in root length of established 
Table 1: Comparison of the infrared main vibrational modes $\left(\mathrm{cm}^{-1}\right)$ for scopolamine (A) and hyocyamine (B) standards with those of control and irradiated Datura stramonium seeds

\begin{tabular}{|c|c|c|c|c|c|c|c|}
\hline \multirow{2}{*}{$\begin{array}{l}\text { (A) } \\
\text { References } \\
\text { scopolamine Band } \\
\left(\mathbf{c m}^{-1}\right)\end{array}$} & \multicolumn{7}{|c|}{ Radiations doses of Datura stramonium seeds - Obtained bands } \\
\hline & D0 & D1 & D2 & D3 & $\mathrm{D} 4$ & D5 & D6 \\
\hline \multirow{3}{*}{$\begin{array}{ll}1730 & (1) \\
853 & (2)\end{array}$} & 3009.0 & 2926.5 & 2925.7 & 2926.6 & 3733.6 & 3786.2 & 3289.8 \\
\hline & 2926.1 & 2855.0 & 1746.4 & 2855.0 & 3675.5 & 3625.8 & 2926.3 \\
\hline & 2854.7 & 1742.9 & 1460.2 & 1743.0 & 2925.7 & 2926.6 & 2854.8 \\
\hline $1166(3)$ & 2360.1 & 1462.9 & 599.0 & 1164.5 & 2854.6 & 2855.0 & 1743.4 \\
\hline $736 \quad$ (4) & 1746.2 & 1166.6 & 546.1 & 1101.8 & 2361.0 & 1743.5 & 1661.6 \\
\hline \multirow{2}{*}{$705 \quad$ (5) } & 1650.1 & & 440.1 & & 2939.3 & 1456.2 & 1549.5 \\
\hline & 1540.1 & & & & 1746.3 & 1258.1 & 1463.0 \\
\hline \multirow[t]{4}{*}{$1047 \quad(6)$} & 1460.5 & & & & & 845.6 & 1164.8 \\
\hline & 1163.0 & & & & & 623.9 & 723.6 \\
\hline & 722.1 & & & & & 547.1 & \\
\hline & 486.7 & & & & & & \\
\hline
\end{tabular}

\section{(B)}

References

\begin{tabular}{|c|c|c|c|c|c|c|c|}
\hline $\begin{array}{l}\text { hyoscyamine Band } \\
\left(\mathbf{c m}^{-1}\right)\end{array}$ & D0 & D1 & D2 & D3 & D4 & D5 & D6 \\
\hline $1720(7)$ & 3009.0 & 2926.5 & 2926.7 & 2926.6 & 3852.2 & 2926.6 & 2926.3 \\
\hline 1035 (8) & 2926.1 & 2855.0 & 2854.5 & 2855.0 & 3840.1 & 1743.5 & 2854.8 \\
\hline 1153 (9) & 2854.7 & 1742.9 & 1746.4 & 1743.0 & 3615.9 & 1456.2 & 1743.4 \\
\hline $\begin{array}{l}1163(10) \\
1063(11)\end{array}$ & 2360.1 & 1462.9 & 1460.2 & 1463.1 & 3567.1 & 1258.1 & 1164.8 \\
\hline \multirow[t]{7}{*}{1204 (12) } & 1746.2 & 1166.6 & 599.0 & 1164.5 & 2925.7 & 845.6 & \\
\hline & 1650.1 & & 546.1 & 1101.8 & 2854.6 & 623.9 & \\
\hline & 1540.1 & & 440.1 & 471.5 & 2364.0 & 547.1 & \\
\hline & 1460.5 & & & & 2339.3 & 442.2 & \\
\hline & 1163.0 & & & & 1746.3 & & \\
\hline & 722.1 & & & & & & \\
\hline & 486.7 & & & & & & \\
\hline
\end{tabular}

(1) Corresponds to the 1730 to $1715 \mathrm{~cm}^{-1}$ band, $C=0, \alpha, \beta$-unsaturated ester. (2) (4) and (5) correspond to the interval of the $900-675$ bands, $\mathrm{CH}$ Aromatic. (3) Represents the interval of 1250-1020 bands, CN, aliphatic amines. (6) Corresponds to the interval of 1320-1000, C -0 , alcohol, carboxylic acid, ester and ether. (7) Corresponds to the interval of 1740-1720, $\mathrm{C}=0$, saturated aliphatic aldehydes. (8, 9, 11, 12) Corresponds to the interval of 1250-1020, CN, aliphatic amines. (10) Corresponds to the interval of 1300-1150, CH Alide alkyl.

seedlings in response to irradiation of seeds (Figs. $3,4)$. In fact increase in stem length was evident at (D2, D3 and D4), whereas reduction occurred at other doses (Fig. 4a). The highest rate of decrease in stem length was $(-30.03)$ at D6. On the other hand, reduction in root length was observed in all radiation doses tested and recorded the maximum at D6 (- 46.76\%) (Fig. 4b).

Interestingly different studies have shown that parameters as seeds germination and plant growth rate are affected also by gamma irradiations and chemical mutagens. In the present study, germination percentage is stimulated with all doses except D5. Therefore, Irradiation of Datura stramonium seeds could be used in the future to improve their germination Ability. The obtained results are in agreement with Kouchebagh and Mirshekari (42) on D. stamonium fesor effects evaluation of some physical seeds material on germination. The results revealed that the highest germination rate was due to seeds treated by gamma irradiation. These results are in partial agreement with the finding of Thapa on Pinus spp., and that of Melki and Dahmani on wheat $(43,44)$. In fact, according to the above mentioned studies low doses of gamma irradiation lead to an increase in the germination rate. Enhanced germination can be attributed to effects of irradiation on the elimination of some pests that are thought to affect seed germination (45), parallel increase in the DNA and protein amounts (46), and / or synthesis or activation of growth hormones (47). This agrees with the generalization drawn by (48) that plants exposed to low doses of gamma rays develop normally or may evince growth stimulation, whereas high doses (like 50Gy) can inhibit their growth. The effect of radiation on the average length of stems and roots was significant. Stem length showed an increase while root length remained unchanged at relatively lower doses, but both stem and root showed a significant decrease at higher doses (D6) (Figs. 3, 5). The rate of reduction/ increase in the plant axis (shoots and roots) did not follow per say a regular pattern and was not dose-dependent (49).The significant increase in shoot length of $D$. stramonium at low doses (D2, D3 and D4) could be due to stimulated cell division and /or cell elongation (49). However, at higher doses a reduced growth rate was recorded, possibly because of alteration of metabolic processes resulting from nucleic - acid disruption, which in turn, disrupted the hormonal system. It can be 


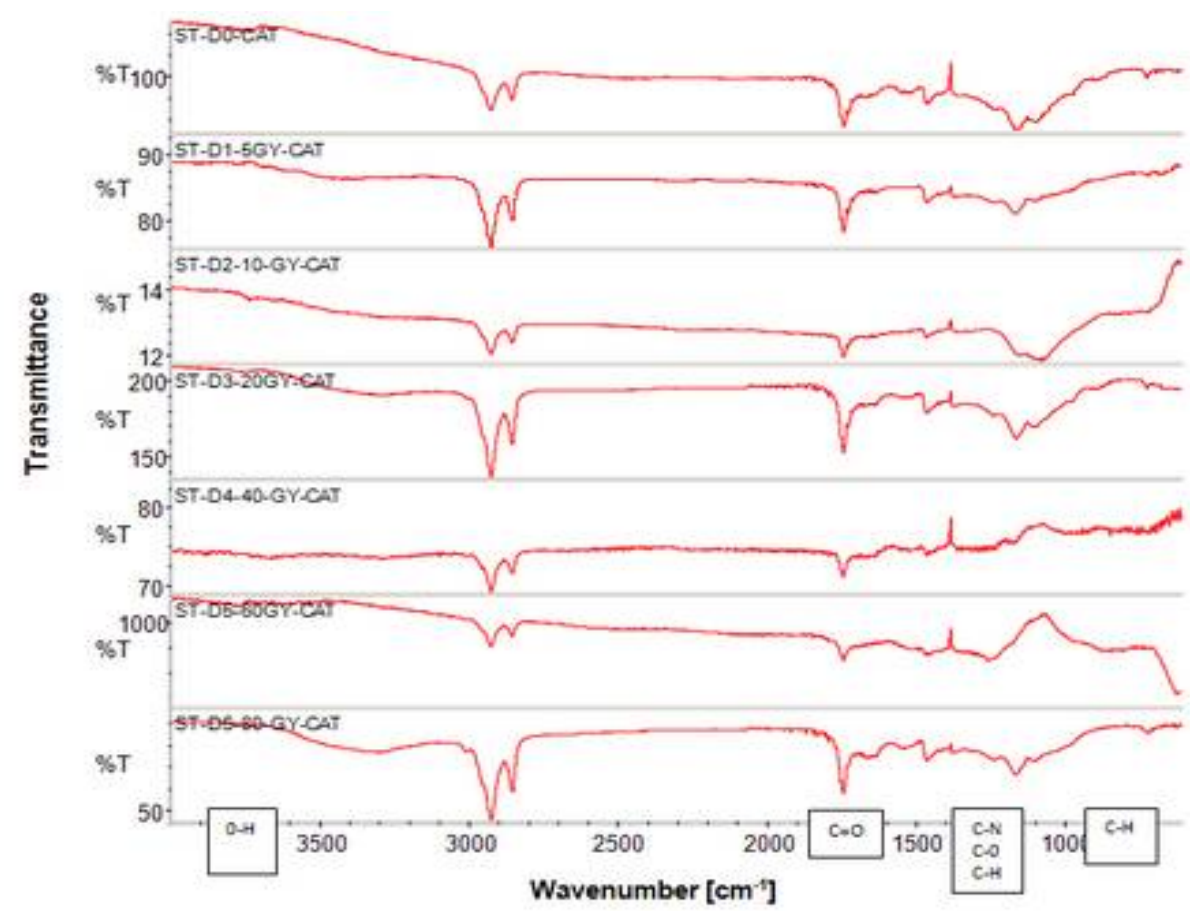

Fig.1. Infrared spectra general appearance of the control and irradiated Datura stramonium seeds at different doses of irradiation

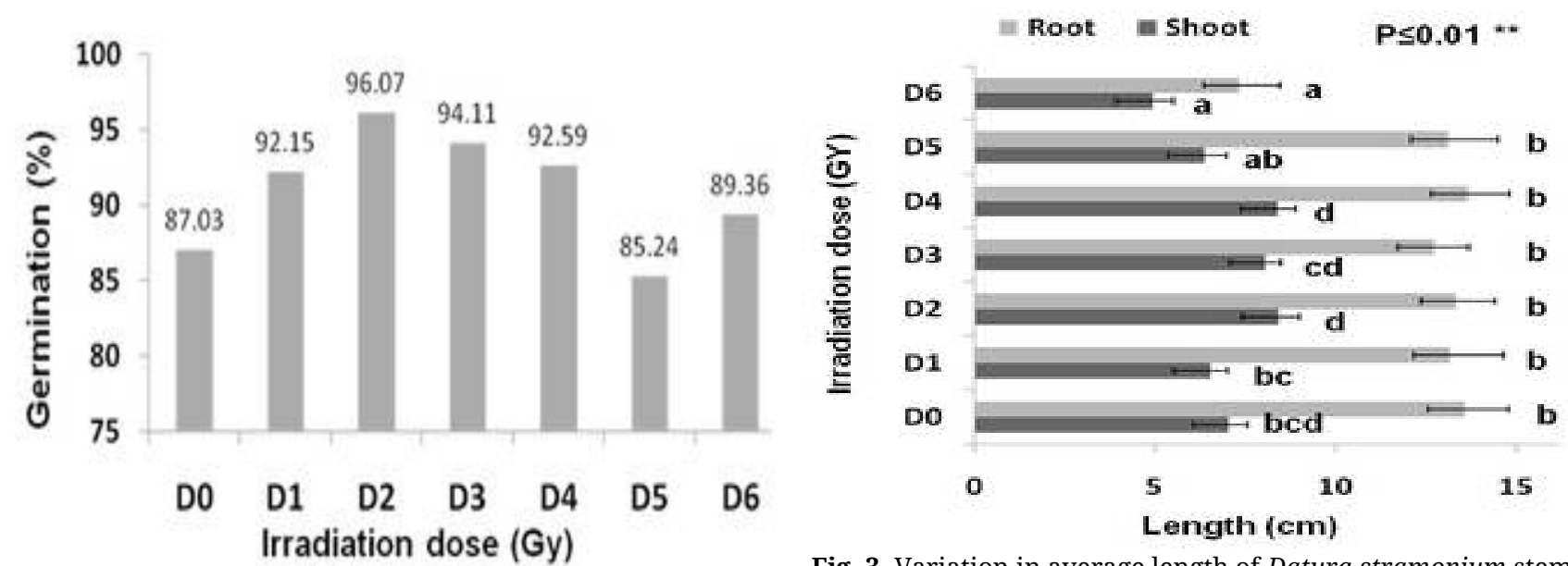

Fig. 2. Effect of different gamma irradiation doses on the Datura stramonium seed germination

Fig. 3. Variation in average length of Datura stramonium stems (A) and root (B) in response to doses of irradiation employed.** The effect was significant at $(P<0.01)$

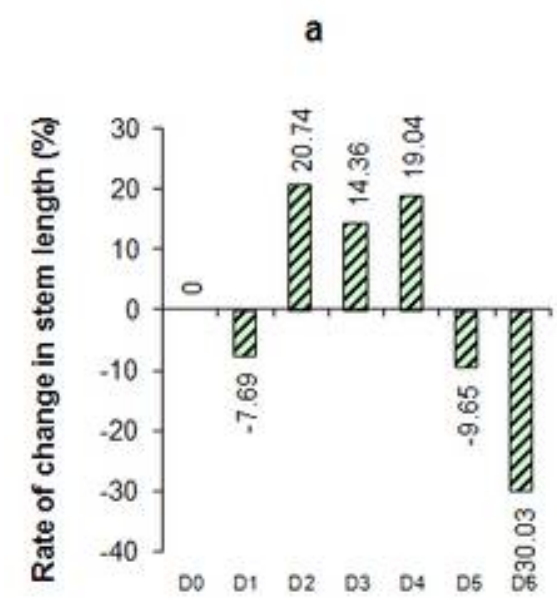

Irradiation dose (Gy)

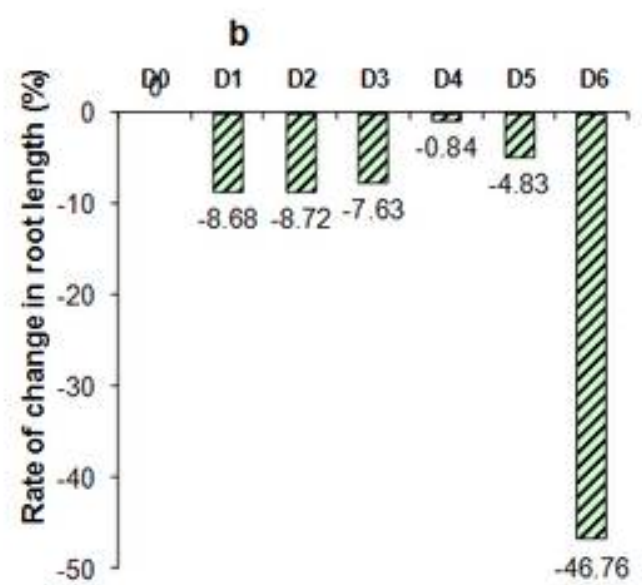

Irradiation dose (Gy)

Fig. 4. Rate of change (reduction/ increase) in (A) stem and (B) root length in response to irradiation intensity 
related to reduction in mitotic cell division in the apical meristem $(50,51)$.

On the other hand, adverse effects of increase in gamma irradiation dose on seed germination and subsequent seedling growth in other plants are well documented $(41,52,53)$. The increased frequency of chromosomal damage associated with higher doses may be responsible for reduced germination and seedlings survival rate (46). High doses of irradiation can additionally cause an inhibition of mitotic divisions (53), resulting from the alteration of certain substances (such as alkaloids) in the seeds.

To determine the suitable irradiation dose for future breeding of plants GR 30-50 should be determined. GR 30-50 could be defined as the dose that cause $30-50 \%$ inhibited germination of cultured seeds. However, in the present study, seed germination exceeded $50 \%$ whatever dose was applied and was approximately equal or higher compared to the control. The GR50 was defined as dosage that causes $30-50 \%$ decrease in growth $(54,55)$ used another criterion as the dosage that caused considerable physiological damage where leaf count and primordial damage was given weight in his case.

According to $(56,57)$ reduction in seedling height of $30-50 \%$ is generally assumed to produce high incidence mutation rate, and therefore, was adopted for Datura stramonium in the present study. The reduction rate of the stem and root length of Datura stramonium in the present investigation was $(-30.03 \%$ and $-46.76 \%$, respectively) at $80 \mathrm{~Gy}$. This indicates that $D$. stramonium seeds are radiosensible at this dose where a physiological damage to shoot and root growth in response to irradiation is in range of (30$50 \%$ ) in comparison to control (Figs. 3, 5). Reduction of the stem and root lengths with increasing doses of radiation has been observed in several species like peanuts, Okra and maize (58).

\section{Conclusion}

Radiosensitivity study of seeds is often applied in plant improvement and breeding programs. This study explored the effect of different doses of cobalt -60 gamma rays on the seed germination and stems/ roots growth of D. stramonium. It is clear, from the results obtained on seeds irradiation for the parameters studied in vitro that GR50 is reached at $80 \mathrm{~Gy}$. The selection of optimal dosage was based on $30 \%$ to $50 \%$ reduction rate in stem and root length in comparison to the control. This dose will be selected for seeds' irradiation of Datura stramonium with the purpose of producing mutant lines capable of producing more enhanced tropane alkaloids profile. Further research should be taken that aims at quantitatively studying tropane alkaloid production in mutant plants of Datura stramonium. Additionally, it is important to reveal the effects of radiation by studying the genes involved in tropane alkaloids biosynthesis pathway, their epigenetic regulation and transcriptional activation mechanisms at different levels.

\section{Acknowledgements}

The authors thank the team of the Algerian Nuclear Research Center which manages the analyzes on the infrared equipment used to carry out this work.

\section{Authors' contributions}

All authors have done the experiments and prepared the article content.

\section{Competing Interests}

The authors declared that they have no conflict of interest.

\section{References}

1. Robins RJ, Parr AJ, Bent EG, Rhodes MJC. Studies on the biosynthesis of tropane alkaloids in Datura stramonium L transformed root cultures. Planta. 1991;183:196-201. https://doi.org/10.1007/BF00197787

2. Butnariu M. An analysis of Sorghum halepense's behavior in presence of tropane alkaloids from Datura stramonium extracts. Chem Cent J. 2012;6-75. https://doi.org/10.1186/1752-153X-6-75

3. Brown JH. Atropine, scopolamine, and related antimuscarinic drugs. In: Goodman GA, editors. The pharmacological basis of therapeutiesrall TW Nies AS. 8nd ed. Taylor $\mathrm{p}$ Goodman and Gilman's, Pergamon. New York; 1990. p. 150-65.

4. Medical and Pharmacy Editor: John P. Cunha, DO, FACOEP. Atropine VS. Adrenalin. Available from: https:// www.rxlist.com/atropine vs adrenalin/drugscondition.htm.2005-2019

5. Hopkins WG. Physiologie végétale. De Boeck Université (Bruxelles); 2003.

6. Verdrager J. Ces médicaments qui nous viennent des plantes ou les plantes médicinales dans les traitements modernes. Maloine SA (France); 1978.

7. Grynkiewicz G, Gadzikowska M. Tropane alkaloids as medicinally useful natural products and their synthetic derivatives as new drugs. Pharmacol Rep.2008;60(4):43963.

8. Toivonen L. Utilization of hairy root cultures for production of secondary metabolites. Biotechnol. Prog. 1993; 9112-20. https://doi.org/10.1021/bp00019a002

9. Bourgaud F, Gravot A, Milesis S, Gatier E. Production of plant secondary metabolites. A historical perspective. Plant Sci. 2001;(5):839-51. https://doi.org/10.1016/S01689452(01)00490-3

10. Dessouky MM, Taha HS, El-Bahr MK. Enhancement of alkaloids production in suspension cultures of Datura stramonium L. and Datura metel L. Arab J Biotech. 2001;4 (2):271-78. 
11. Kinsara AM, Seif El-Nasr MM.Organization and alkaloid production in tissue culture of Datura innoxia Mill. JKAU:Sci. 1994;6:5-15. https://doi.org/10.4197/Sci.6-1.1

12. Makhzoum A, Petit-Paly G, St-Pierre B, Bernards MA. Functional analysis of the DAT gene promoter using transient Catharanthus roseus and stable Nicotiana tabacum transformation systems. Plant Cell Rep. 2011;30:1173-82. https://doi.org/10.1007/s00299-011-1025y

13. Makhzoum A, Bjelica A, Petit-Paly G, Bernards MA. Novel plant regeneration and transient gene expression in Catharanthus roseus. The All Results Journals: Biol. 2015;6:1-9.

14. Habibi P, Grossi MF, Makhzoum A, Malik S, da silva ALL, Hefferon KL, Soccol CR. Bioengineering hairy roots: Phytoremediation, secondary metabolism, molecular pharming, plant-plant interactions and biofuels. In: Lichtfouse E, editors Sustainable Agriculture reviews, Springer Nature;2017. p. 213-51. https://doi.org/10.1007/978-3-319-48006-0 7

15. Guillon S, Tremouillaux-Guiller J, Pati PK, Rideau M, Gantet P. Hairyroot research: Recent scenario and exciting prospects. Current Opinion in Plant Biology. 2006;9:341-46. https://doi.org/10.1016/j.pbi.2006.03.008

16. Kim y, Wyslouzil BE, Weathers PJ. Secondary metabolism of hairyroot culture in Bioreactors. In vitro cellular\&Developmental- Biology Plant. 2002;38:1-10. https://doi.org/10.1079/IVP2001243

17. Lanoue A, Shakourzadeh K, Marison I, Laberche JC, Christen P, Sangwan-Norrel B, et al. Occurrence of circadian rhythm in hairyroot cultures grown under controlled conditions. Biotechnology Bioeng 2004;88:72229. https://doi.org/10.1002/bit.20268

18. Flores HE, Medina-Bolivar F. Root culture and plant natural products: "unearthing» the hidden half of plant metabolism. Plant Tissue culture and Biotechnology. 1995;(1,2): 59-74.

19. Souret FF, Kim Y, Wyslouzil BE, Wobbe KK et Weathers PJ. Scale-up of Artimisia annua L. Hairyroot cultures produces complex patterns of terpinoid gene expression. Biotechnology and Bioengineering. 2003;83(6):653-69. https://doi.org/10.1002/bit.10711

20. Zhi-Bi $\mathrm{Hu}$, Min Du. Hairyroots and its application in plant genetic engineering. Journal of Integrative Plant Biology. 2006;48(2):121-27. https://doi.org/10.1111/j.17447909.2006.00121.x

21. Makhzoum A, Sharma P, Bernards MA, TrémouillauxGuiller J. Hairy roots: an ideal platform for transgenic plant production and other promising applications. In: Phytochemicals, Plant Growth, and the Environment. Springer, New York; $2013 . \quad$ p. 95-142. https://doi.org/10.1007/978-1-4614-4066-6 6

22. Makhzoum A, Benyammi R, Moustafa K, TrémouillauxGuiller J. Recent advances on host plants and expression cassettes' structure and function in plant molecular pharming. BioDrugs. 2014;28(1):45-159. https://doi.org/10.1007/s40259-013-0062-1

23. Malik S, Andrade SA, Mirjalili MH, Arroo RR, Bonfill M, Mazzafera P. Biotechnological Approaches for Bioremediation: In Vitro Hairy Root Culture. In: Sumita Jha, editors. Transgenesis and Secondary metabolism, Springer International Publishing; 2017; p. 597-619. https://doi.org/10.1007/978-3-319-28669-3 28

24. Harfi B, Khelifi-Slaoui M, Bekhouche M, Benyammi R, et al. Hyoscyamine production in hairy roots of three Datura species exposed to high-salt medium. In Vitro Cell Dev Biol-Plant. 2016;52:92-98
25. Belabbassi O, Khelifi-Slaoui M, Zaoui D, Benyammi R et al. Synergistic effects of polyploidization and elicitation on biomass and hyoscyamine content in hairy roots of Datura stramonium. Base [Internet]. 2016 [cited 2015 Dec 17]. Available from http://popups.ulg.ac.be/17804507/index.php?id=13164

26. Benyammi R, Paris C, Khelifi-Slaoui M, Zaoui D, Belabbassi $\mathrm{O}$ et al. Screening and kinetic studies of catharanthine and ajmalicine accumulation and their correlation with growth biomass in Catharanthus roseus hairy roots. Pharm Biol. 2016;54:2033-43. https://doi.org/ $10.3109 / 13880209.2016 .1140213$

27. Harfi B. Induction de chevelus racinaires par Agrobacterium rhizogenes chez Datura sp. Essai d'optimisation de la production d'alcaloïdes. Thèse Magistère ENSA, El Harrach Alger; 2009.

28. Amdoun R. Optimisation de la production par voie biotechnologique des alcaloïdes tropaniques à partir de chevelus racinaires de Datura stramonium L. Approche par modélisation mathématique. Thèse Doc Sci ENSA, El Harrach Alger; 2010.

29. Chung BY, Lee YB, Baek MH, Kim JH, Wi SG, Kim JS. Effects of low-dose gamma-irradiation on production of shikonin derivatives in callus cultures of Lithospermum erythrorhizon S. Radiation Phys Chem. 2006; 75:1018-23. https://doi.org/10.1016/j.radphyschem.2005.11.001

30. Khelifi-Slaoui M, Rezine MR, Amroun S, Amdoun R, Khelifi L. Embryons somatiques et bourgeons néoformés induits sur explants issus de vitrosemis de Datura stramonium L. d'origine algérienne. In: Khelifi L, éditeur. Actes du séminaire international sur l'amélioration des productions végétales, Alger; 2005. p 114-18.

31. Murashige T, Skoog F. A revised medium for rapid growth and bioassays with tobacco tissue culture. Plant Physiol. 1962;15:473-97. https://doi.org/10.1111/j.13993054.1962.tb08052.x

32. Gogebashvili M, Ivanishvili N, FKhaladze L, Popiashvili $\mathrm{N}$. The influence of gamma-irradiation on the activity of alkaloids biosynthesis in cultural callus tissues. Radiation studies. Georgian Research Institute for Scientific Technical Information; 2002.

33. Gaul H. Mutageneffects in the first generation after seeds treatment. In: Welsh C.N, Micke A, editors. Manual on Mutation Breeding, 2nd ed. 119 IAEA, Technical Reports Series. Vienna; 1977. p. 87-91.

34. Moffat AC, Osselton MD, Widdop B, Watts J. Clarkc's analysis of drugs and poisons. 4nd ed. Pharmaceutical Press. London; 2011.

35. Jean FI. Analyse de produits naturels de Taxus canadensis. Thèse de doctorat, Québec CFFL Canada; 1992. https://doi.org/10.1522/1474504

36. Naumann A, Kurtze L, Krähmer A, Hagels H, Schulz H. Discrimination of Solanaceae Taxa and quantification of scopolamine and hyoscyamine by ATR-FTIR spectroscopy. Planta Med. 2014; 80:1315-20 https://doi.org/10.1055/s-0034-1383046

37. Kim JB, Kim SH, Ha BK, Kang SY, Jang CS, Seo YW, et al. Differentially expressed genes in response to gammairradiation during the vegetative stage in Arabidopsis thaliana. Mol Biol Rep. 2014;41:2229-41. https://doi.org/10.1007/s11033-014-3074-0

38. Kobayashi JK, Iwabuchi K, Miyagawa E, Sonoda $\mathrm{K}$ et al. Current topics in DNA double-strand break repair. J Radiat. Res. 2008;49:93-103. https://doi.org/10.1269/jrr.07130 
39. Dedieu A, Sahinovic E, Guérin P, Blanchard L, Fochesato $\mathrm{S}$, Meunir B et al. Major soluble proteome changes in Deinococcus deserti over the earliest stages following gamma-ray irradiation. Proteome Sci. 2013;11:3. https://doi.org/10.1186/1477-5956-11-3

40. Kovács E, Keresztes A. Effect of gamma and UV-B/C radiation on plant cells. Micron. 2002;33:199-210. https:// doi.org/10.1016/S0968-4328(01)00012-9

41. Nakweti RK, Ndiku SL, Sinou V, Luyeye FL, Fundu TM et al. Effects of gamma irradiation on seeds germination, plantlets growth and in vitro antimalarial activity of Phyllanthus odontadenium Mül Arg. American Journal of Experimental Agriculture. 2014;4:1435-57. https://doi.org/10.9734/AJEA/2014/8631

42. Kouchebagh SB, Mirshekari B. Invigoration of Datura stramonium seeds by magnetic field treatment. Ind J fund appl life sci. 2015;5:164-68.

43. Thapa CB. Effect of Acute Exposure of Gamma Rays on Seed Germination and Seedling Growth of Pinus kesiya Gord and $P$. wallichiana A.B. Jacks. Our Nature, 2004;2:13-17. https://doi.org/10.3126/on.v2i1.318

44. Melki M, Dahmani T. Gamma irradiation effects on Durum wheat (Triticum durum.Desf) under various conditions.J biol Sci. 2009;12:1531-34. https://doi.org/10.3923/pjbs.2009.1531.1534

45. Bilquez A, Martin J. Différence variétale de sensibilité aux rayons x chez l'arachide. Journ d'Agric. Trop et de botanique appliquée. 1961;8:30-43. https://doi.org/10.3406/jatba.1961.6894

46. Kiong ALP, Lai AG, Hussein S, Harun AR. Physiological responses of Orthosiphon stamineus plants to gamma irradiation. Am-Eurasian J Sustain. Agric. 2008;2:135-49.

47. Bilquez A. Résultats d'un essai de stimulation de croissance chez le Radis par application de faible doses de rayons $\mathrm{x}$ aux graines avant le semis. Journ d'AgricTrop et de botanique appliquée. 1958;5:365-71. https://doi.org/10.3406/jatba.1958.2471

48. Seung CW, Byung YG, Jea S, Jin HK, Myung B, Hwa, JW Lee, et al. Effects of gamma radiation on morphological changes and biological responses in plants. Micron. 2006;38:553-64.

https://doi.org/10.1016/j.micron.2006.11.002
49. Badr HM, Alsadon AA, Al Harbi AR. Stimulation effects of gamma radiation on growth and yield of two tomato (Lycopersicum esculentum Mill) cultivars. Agri Sci. 1997;9:277-86.

50. Rajput MA, Siddiqui KA. Induced mutation breeding studies for soybean improvement. In: Induced mutations for improvement of grain legume production Proceedings of $3^{\text {rd }}$ Research Co-ordination Meeting; 1983 May 28-1 June; FAO/IAEA division, Vienna; 1983. p. 16570.

51. Abdul M, Asif U, Habib A, Zahir M. Gamma irradiation effects on some growth parameters of Lepidum sativum L. J Ag \& Bio Sci. 2010;5:39-42.

52. Amjad M, Anjum M. Effect of gamma radiation on onion seed variability, germination potential, seedling growth and morphology. Agri Sci. 2002;39:202-09.

53. Hameed A, Shah TM, Atta BM, Haq MA, Sayed H. Gamma irradiation effects on seed germination and growth, protein content, peroxidase and protease activity, lipid peroxidation in Desi and Kabuli chickpea. Pak J Bot. 2008;40:1033-41.

54. Alikamanoğlu S. Efficiency of the gamma irradiation in the induction of in vitro somatic mutations. Journal of Cell and Molecular Biology. 2002;1:19-24.

55. Brunner $H$. Radiation induced mutations for plant selection. App Radiat Isot. 1995; 46:589-94. https://doi.org/10.1016/0969-8043(95)00096-8

56. Kamra OP, Brunner H. Chemical mutagens. Doses. In: Welsh CN, Micke A, editors. Manual on Mutation Breeding, 2nd ed. 119 IAEA, Technical Reports Series. Vienna; 1977. p. 66-69.

57. Benslimani N. Etude du comportement de l'arachide (Arachis hypogaea L.) issue de graines soumises à des traitements mutagènes (rayon gamma, Cobalt-60). Thèse magistère ENSA, El Harrach Alger; 2003.

58. Mokobia C, Anomohanran O. The effect of gamma radiation on the germination and growth of certain Nigerian agricultural crops. J Radiol Prot. 2005;25:18188. https://doi.org/10.1088/0952-4746/25/2/006 